\section{JURNAL EKONOMI EFEKTIF}

ISSN : $2622-8882$, E-ISSN : 2622-9935

Jurnal Ekonomi Efektif, Vol. 4, No. 2, Januari 2022

@ Prodi Manajemen Fakultas Ekonomi

Universitas Pamulang

\title{
PENGARUH STORE ATMOSPHERE TERHADAP KEPUTUSAN PEMBELIAN PADA MCDONALD'S CABANG GRAHA RAYA BINTARO
}

\author{
Rizky Pambudi ${ }^{1}$, Ali Maddinsyah ${ }^{2 *}$ \\ Universitas Pamulang, Tangerang Selatan, Banten, Indonesia \\ pambudirizky2@gmail.com ${ }^{1}$, alimaddinsyah@unpam.ac.id ${ }^{2 *}$ \\ Manuskrip: Desember-2021; Ditinjau: Desember-2021; Diterima: Desember-2021; Online: Januari -2022; \\ Diterbitkan: Januari-2022
}

\begin{abstract}
ABSTRAK
Penelitian ini bertujuan untuk mengetahui pengaruh store atmosphere terhadap keputusan pembelian pada McDonald's Cabang Graha Raya Bintaro. Metode yang digunakan adalah explanatory research dengan sampel sebanyak 96 responden. Teknik analisis menggunakan analisis statistik dengan pengujian regresi, korelasi, determinasi dan uji hipotesis. Hasil penelitian ini variabel store atmosphere diperoleh nilai rata-rata skor sebesar 3,425 dengan kriteria baik. Variabel keputusan pembelian diperoleh nilai rata-rata skor sebesar 3,828 dengan kriteria baik. Store atmosphere berpengaruh positif dan signifikan terhadap keputusan pembelian dengan nilai persamaan regresi $\mathrm{Y}=8,475+0,870 \mathrm{X}$, dan nilai koefisien korelasi 0,769 atau memiliki tingkat hubungan yang kuat dengan nilai determinasi $59,1 \%$. Uji hipotesis diperoleh signifikansi $0,000<0,05$.
\end{abstract}

\section{Kata Kunci: Store Atmosphere, Keputusan Pembelian}

\section{ABSTRACT}

This study aims to determine the effect of store atmosphere on purchasing decisions at McDonald's Graha Raya Bintaro Branch. The method used is explanatory research with a sample of 96 respondents. The analysis technique uses statistical analysis with regression, correlation, determination and hypothesis testing. The results of this study store atmosphere variable obtained an average score of 3,425 with good criteria. The purchase decision variable obtained an average score of 3.828 with good criteria. Store atmosphere has a positive and significant effect on purchasing decisions with a regression equation value of $Y=8.475+$ $0.870 X$, and a correlation coefficient of 0.769 or has a strong relationship with a determination value of $59.1 \%$. Hypothesis testing obtained a significance of $0.000<0.05$.

Keywords: Store Atmosphere, Purchase Decision 


\section{PENDAHULUAN}

\section{A. Latar Belakang}

Bisnis restoran siap saji semakin marak diberbagai kota, dengan ditopang oleh sentimen membaiknya pendapatan masyarakat serta meningkatnya tren bersantap di luar rumah. Restoran siap saji merupakan salah satu subsektor industri kuliner dengan kinerja cukup stabil. "Restoran siap saji tumbuh stabil dan akan semakin baik. Selain itu, tren makan di luar rumah pun makin meningkat. "Kaum milenial menang membuat temanteman dan keluarganya untuk sering makan di luar. Dengan demikian tantangan mendasar yang dihadapi oleh pengusaha restoran siap saji saat ini adalah perencanaan bisnis. Pasalnya, mereka tidak lagi mengandalkan pusat perbelanjaan sebagai tempat berjualan, tetapi di wilayah-wilayah yang padat penduduk. Permasalahannya sering kondisi store atmphere kurang nyaman dan bisisng sehingga dapat mengganggu penjualan

McDonald's sebagai salah satu industri makanan cepat saji yang sudah banyak dikenal masyarakat tentu harus memiliki strategi yang tepat dalam menjaga dan memeuhi harapan konsumennya. Saat ini sudah semakin banyak produsen cafe and resto yang terlibat dalam pemenuhan kebutuhan dan keinginan konsumen. Hal tersebut membuat pengusaha starbucks harus berupaya untuk memahami kebutuhan, keinginan, dan permintaan pasar sasaran. Pengusaha tersebut harus berupaya untuk mendapatkan perhatian serta ketertarikan khalayak ramai (dalam hal ini calon konsumen), karena mereka bersaing dengan perusahaan yang memiliki produk serupa. Maka dari itu setiap pengusaha dengan jenis produk serupa harus memikirkan cara untuk menangkan pasar. Lokasi cabang / kantor McDonald's Graha Raya Bintaro di Kota Tangerang Selatan, Banten. Terdapat banyak pilihan mcdonald's menu yang dapat dipilih oleh pelanggan, mcd menu yang tersedia mulai dari berupa paket untuk sendiri hingga kelompok, cocok untuk makan bersama keluarga. Selain itu menu mcdo juga sudah di pesan secara online ataupun via mcdelivery, kunjungi gerai MC D ini atau datang langsung ke MCD terdekat.

Salah satu cara untuk memenangkan persaingan adalah dengan membuat sesuatu yang berbeda. Store atmosphere bisa menjadi alternatif untuk membedakan cafe yang satu dengan yang lainnya. Perbedaan diperlukan karena dari setiap bisnis pasti didapati produk yang serupa dengan harga yang berkisar beda tipis bahkan sama. Store atmosphere bisa menjadi alasan lebih bagi konsumen untuk tertarik dan memilih dimana ia akan berkunjung dan membeli. Hal ini seperti yang dikemukakan oleh Levy dan Weitz (2001:556) "Customer purchasing behavior is also influenced by the store atmosphere". Dalam keputusan pembelian, konsumen tidak hanya memberi respon terhadap barang dan jasa yang ditawarkan, tetapi juga memberikan respon terhadap lingkungan pembelian yang menyenangkan bagi konsumen. Membuat konsumen tertarik adalah salah satu tujuan awal dan selanjutnya pasti bertujuan untuk mendorong hasrat konsumen untuk membeli. Store atmosphere yang ditawarkan produsen, jika ditanggapi dengan positif oleh konsumen akan memperoleh peluang besar bagi tempat tersebut untuk dikunjungi.

Suasana yang mengacu pada desain dari lingkungan melalui komunikasi visual, pencahayaan, warna, musik, dan aroma yang merangsang pelanggan secara perseptual dan emosional serta pada akhirnya mempengaruhi perilaku pembelian mereka dapat diasumsikan bahwa penilaian atau tanggapan konsumen terhadap store atmosphere akan mempengaruhi pembelian konsumen. Salah satu yang menjadi pertimbangan dalam pengambilan keputusan pembelian adalah store atmosphere yang menarik.

Store atmosphere tidak hanya berpengaruh terhadap keputusan pembelian, tetapi juga berpengaruh terhadap kepuasan pelanggan. Ryu dan Han (2010) dalam Heung dan $\mathrm{Gu}$ (2012) menyatakan bahwa "Although all determinants of customer satisfaction deserve attention in research and practice, atmospherics may, to a large extent, determine 
the overall degree of such satisfaction in the restaurant industry". Meskipun semua faktor penentu kepuasan pelanggan perlu diperhatikan dalam penelitian dan praktek, untuk sebagian besar mungkin suasana menentukan tingkat keseluruhan kepuasan di industri restoran.

Store atmosphere merupakan kombinasi dari hal- hal yang bersifat emosional. Menurut Mowen dan Minor (2002:139) store atmosphere mempengaruhi keadaan emosional pembelanja, yang kemudian mendorong untuk meningkatkan atau mengurangi belanja. Dampak dari store atmosphere dapat menciptakan kesan yang membuat pembeli akan meningkatkan pembeliannya atau hanya membeli secukupnya dan kemungkinan tidak berniat kembali lagi untuk membeli di tempat tersebut.

Berdasarkan pemaparan pada latar belakang masalah di atas, maka penulis tertarik melakukan penelitian dengan judul "Pengaruh Store atmosphere Terhadap Keputusan Pembelian Konsumen Pada McDonald's Cabang Bintaro Tangerang".

\section{B. Rumusan Masalah}

a. Bagaimana store atmosphere pada McDonald's Cabang Graha Raya Bintaro ?.

b. Bagaimana keputusan pembelian pada McDonald's Cabang Graha Raya Bintaro ?.

c. Adakah pengaruh antara store atmosphere terhadap keputusan pembelian pada McDonald's Cabang Graha Raya Bintaro ?.

\section{C.Tujuan Penelitian}

a. Untuk mengetahui kondisi store atmosphere pada McDonald's Cabang Graha Raya Bintaro.

b. Untuk mengetahui kondisi keputusan pembelian pada McDonald's Cabang Graha Raya Bintaro.

c. Untuk mengetahui pengaruh store atmosphere terhadap keputusan pembelian pada McDonald's Cabang Graha Raya Bintaro.

\section{TINJAUAN PUSTAKA}

\section{Store Atmosphere}

Menurut Bermen dan Evan (2018:455) berpendapat Store atmosphere merupakan salah satu unsur dari retailing mix yang juga harus diperhatikan oleh suatu bisnis ritel yang meliputi tata letak dan suasana. Dengan adanya store atmosphere yang baik, perusahaan dapat menarik konsumen untuk berkunjung dan melakukan pembelian.

\section{Keputusan Pembelian}

Menurut Kotler dan Amstrong (2019) berpendapat "perilaku konsumen merupakan sebuah pendekatan penyesuaian masalah yang terdiri dari lima tahap yang dilakukan konsumen. Kelima tahap tersebut adalah pengenalan masalah, pencarian informasi, evaluasi alternatif, keputusan pembelian, dan perilaku pasca pembelian".

\section{METODE PENELITIAN}

\section{Populasi}

Yang dijadikan sebagai populasi dalam penelitian ini adalah responden yang berjumlah 96 responden McDonald's Cabang Graha Raya Bintaro

\section{Sampel}

Teknik pengambilan sampling dalam penelitian ini adalah sampel jenuh, dimana semua anggota populasi dijadikan sebagai sampel. Dengan demikian sampel dalam penelitian ini sampel yang digunakan berjumlah 96 responden. 


\section{Jenis Penelitian}

Jenis penelitian yang dipakai adalah asosiatif, dimana tujuannya adalah untuk mengetahui atau mencari keterhubungan antara variabel independen terhadap variabel dependennya

\section{Metode Analisis Data}

Dalam menganalisis data digunakan uji validitas, uji reliabilitas, analisis regresi linier sederhana, analisis koefisien korelasi, analisis koefisien determinasi dan pengujian hipotesis.

\section{HASIL PENELITIAN}

\section{Analisis Deskriptif}

Pada pengujian ini digunakan untuk mengetahui skor minimum dan maksimum skor tertinggi, ratting score dan standar deviasi dari masing-masing variabel. Adapun hasilnya sebagai berikut:

Tabel 1. Hasil Analisis Descriptive Statistics

Descriptive Statistics

\begin{tabular}{|l|r|r|r|r|r} 
& N & Minimum & Maximum & Mean & \multicolumn{1}{c}{ Std. Deviation } \\
\hline Store Atmosphere (X) & 96 & 28 & 44 & 34.25 & 3.722 \\
\hline Keputusan Pembelian (Y) & 96 & 29 & 48 & 38.28 & 4.212 \\
\hline Valid N (listwise) & 96 & & & & \\
\hline
\end{tabular}

Store atmosphere diperoleh varians minimum sebesar 28 dan varians maximum 44 dengan ratting score sebesar 3,425 dengan standar deviasi 3,722. Skor ini termasuk pada rentang sakala 3,40-4,19 dengan kriteria baik atau setuju. Keputusan pembelian diperoleh varians minimum sebesar 29 dan varians maximum 48 dengan ratting score sebesar 3,828 dengan standar deviasi 4,212. Skor ini termasuk pada rentang sakala 3,40 $-4,19$ dengan kriteria baik atau setuju.

\section{Analisis Kuantitatif}

Pada analisis ini dimaksudkan untuk mengetahui pengaruh variabel independen terhadap variabel dependen. Adapun hasil pengujian sebagai berikut:

\section{a. Analisis Regresi Linier Sederhana}

Uji regresi ini dimaksudkan untuk mengetahui perubahan variabel dependen jika variabel independen mengalami perubahan. Adapun hasil pengujiannya sebagai berikut:

Tabel 2. Hasil Pengujian Regresi Linier Sederhana

\begin{tabular}{|c|c|c|c|c|c|c|}
\hline & & & oefficients & & & \\
\hline & & $\begin{array}{r}\text { Unst } \\
\mathrm{Co}\end{array}$ & $\begin{array}{l}\text { dardized } \\
\text { ficients }\end{array}$ & $\begin{array}{l}\text { Standardized } \\
\text { Coefficients }\end{array}$ & & \\
\hline & del & B & Std. Error & Beta & $\mathrm{t}$ & Sig. \\
\hline & (Constant) & 8.475 & 2.571 & & 3.297 & .001 \\
\hline & Store Atmosphere (X) & .870 & 075 & .769 & 11.663 & .000 \\
\hline
\end{tabular}

a. Dependent Variable: Keputusan Pembelian (Y)

Berdasarkan hasil pengujian pada tabel di atas, diperoleh persamaan regresi $\mathrm{Y}$ $=8,475+0,870 X$. Dari persamaan tersebut dijelaskan sebagai berikut:

1) Konstanta sebesar 8,475 diartikan jika store atmosphere tidak ada, maka telah terdapat nilai keputusan pembelian sebesar 8,475 point.

2) Koefisien regresi store atmosphere sebesar 0,870 , angka ini positif artinya setiap ada peningkatan store atmosphere sebesar 0,870 point maka keputusan pembelian juga akan mengalami peningkatan sebesar 0,870 point. 


\section{b. Analisis Koefisien Korelasi}

Analisis koefisien korelasi dimaksudkan untuk mengetahui tingkat kekuatan hubungan dari variabel independen terhadap variabel dependen. Adapun hasil pengujian sebagai berikut:

Tabel 3. Hasil Pengujian Koefisien Korelasi Store Atmosphere Terhadap Keputusan Pembelian.

Correlations $^{\mathbf{b}}$

\begin{tabular}{llr|r} 
& & $\begin{array}{c}\text { Store Atmosphere } \\
(\mathrm{X})\end{array}$ & \multicolumn{1}{c}{$\begin{array}{c}\text { Keputusan } \\
\text { Pembelian (Y) }\end{array}$} \\
\hline Store Atmosphere $(\mathrm{X})$ & Pearson Correlation & 1 & $.769^{* *}$ \\
\cline { 2 - 4 } & Sig. (2-tailed) & & .000 \\
\hline Keputusan Pembelian (Y) & Pearson Correlation & $.769^{* *}$ & 1 \\
\cline { 2 - 4 } & Sig. (2-tailed) & .000 & \\
\hline
\end{tabular}

**. Correlation is significant at the 0.01 level (2-tailed).

b. Listwise $\mathrm{N}=96$

Berdasarkan hasil pengujian diperoleh nilai korelasi sebesar 0,769 artinya store atmosphere memiliki hubungan yang kuat terhadap keputusan pembelian.

\section{c. Analisis Koefisien Determinasi}

Analisis koefisien determinasi dimaksudkan untuk mengetahui besarnya persentase pengaruh dari variabel independen terhadap variabel dependen. Adapun hasil pengujian sebagai berikut:

Tabel 4. Hasil Pengujian Koefisien Determinasi Store Atmosphere Terhadap Keputusan Pembelian. Model Summary

\begin{tabular}{|c|c|c|c|c|}
\hline Model & $\mathrm{R}$ & R Square & $\begin{array}{l}\text { Adjusted R } \\
\text { Square }\end{array}$ & Std. Error of the Estimate \\
\hline 1 & $.769^{\mathrm{a}}$ & .591 & .587 & $\begin{aligned} 2.707\end{aligned}$ \\
\hline
\end{tabular}

Berdasarkan hasil pengujian diperoleh nilai determinasi sebesar 0,591 artinya store atmosphere memiliki kontribusi pengaruh sebesar 59,1\% terhadap keputusan pembelian, sedangkan sisanya sebesar $40,9 \%$ dipengaruhi oleh faktor lain yang tidak dilakukan penelitian.

\section{d. Uji Hipotesis}

Pengujian hipotesis dengan uji tidak digunakan untuk mengetahui hipotesis mana yang diterima. Rumusan hipotesis: Terdapat pengaruh yang signifikan store atmosphere terhadap keputusan pembelian.

Tabel 5. Hasil Uji Hipotesis Store atmosphere Terhadap Keputusan Pembelian.

\begin{tabular}{|c|c|c|c|c|c|}
\hline \multirow[b]{3}{*}{ Model } & \multicolumn{2}{|c|}{ Coefficients $^{\mathbf{a}}$} & \multirow{3}{*}{$\begin{array}{l}\text { Standardized } \\
\text { Coefficients } \\
\text { Beta }\end{array}$} & \multirow[b]{3}{*}{$\mathrm{l}$} & \multirow[b]{3}{*}{ Sig. } \\
\hline & \multicolumn{2}{|c|}{$\begin{array}{l}\text { Unstandardized } \\
\text { Coefficients }\end{array}$} & & & \\
\hline & $\mathrm{B}$ & Std. Error & & & \\
\hline $1 \quad$ (Constant) & 8.475 & 2.571 & & 3.297 & .001 \\
\hline Store Atmosphere $(\mathrm{X})$ & .870 & .075 & .769 & 11.663 & .000 \\
\hline
\end{tabular}

a. Dependent Variable: Keputusan Pembelian (Y)

Berdasarkan hasil pengujian pada tabel di atas, diperoleh nilai t hitung $>\mathrm{t}$ tabel atau $(11,663>1,985)$, dengan demikian hipotesis yang diajukan bahwa terdapat pengaruh yang signifikan atara store atmosphere terhadap keputusan pembelian diterima. 


\section{Pembahasan Hasil Penelitian}

\section{Kondisi Jawaban Responden Variabel Store Atmosphere}

Berdasarkan jawaban responden, variabel store atmosphere diperoleh ratting score sebesar 3,425 berada di rentang skala 3,40 - 4,19 dengan kriteria baik atau setuju.

\section{Kondisi Jawaban Responden Variabel Keputusan Pembelian}

Berdasarkan jawaban responden, variabel keputusan pembelian diperoleh ratting score sebesar 3,828 berada di rentang skala 3,40 - 4,19 dengan kriteria baik atau setuju.

\section{Pengaruh Store Atmosphere Terhadap Keputusan Pembelian}

Store atmosphere berpengaruh signifikan terhadap keputusan pembelian dengan persamaan regresi $\mathrm{Y}=8,475+0,870 \mathrm{X}$, nilai korelasi sebesar 0,769 atau memiliki hubungan yang kuat dengan kontribusi pengaruh sebesar 59,1\%. Pengujian hipotesis diperoleh nilai thitung $>\mathrm{t}$ tabel atau $(11,663>1,985)$. Dengan demikian hipotesis yang diajukan bahwa terdapat berpengaruh signifikan antara store atmosphere terhadap keputusan pembelian diterima.

\section{KESIMPULAN DAN SARAN}

\section{Kesimpulan}

a. Variabel store atmosphere diperoleh ratting score sebesar 3,425 berada di rentang skala 3,40 - 4,19 dengan kriteria baik atau setuju.

b. Variabel keputusan pembelian diperoleh ratting score sebesar 3,828 berada di rentang skala 3,40-4,19 dengan kriteria baik atau setuju.

c. Store atmosphere berpengaruh signifikan terhadap keputusan pembelian dengan persamaan regresi $\mathrm{Y}=8,475+0,870 \mathrm{X}$, nilai korelasi sebesar 0,769 atau kuat dan kontribusi pengaruh sebesar $59,1 \%$ sedangkan sisanya sebesar $40,9 \%$ dipengaruhi faktor lain. Uji hipotesis diperoleh nilai $t$ hitung $>\mathrm{t}$ tabel atau $(11,663>1,985)$.

\section{Saran}

Berdasarkan hasil penelitian di atas, maka penulis memberikan saran sebagai berikut:

a. Pelaksanaan rancangan Store atmosphere hendaknya terus ditingkatkan dari waktu kewaktu dan harus disesuaikan dengan kebutuhan dan keinginan konsumen. Hal ini dilaksanakan sebagai salah satu upaya untuk meningkatkan jumlah pembelian.

b. Berkaitan dengan keputusan pembelian, hendaknya seluruh pengelola dan karyawan berusaha untuk lebih menyesuaikan perancangan Store atmosphere yang ada dengan keinginan dan kebutuhan konsumen, sehingga konsumen merasa bergairah dalam melakukan pembelian yang akan mendukung terjadinya Impulse Buying.

\section{DAFTAR PUSTAKA}

Algifari. (2015). Analisis Regresi untuk Bisnis dan Ekonomi. Yogyakarta: BPFE.

Arikunto, Suharsimi (2014). Prosedur Penelitian Suatu Pendekatan Praktek. Jakarta: Rineka Cipta.

Bashu Swastha dan T. Handoko (2015) Manajemen Pemasaran Moderen, Yogyakarta: BPFE.

Basu Swastha Dharmmesta. (2014). Manajemen Pemasaran. BPFE: Yogyakarta. Buchari Alma. 2014. Manajemen Pemasaran dan Pemasaran Jasa. Edisi Revisi.

Bilson Simamora (2016) Panduan Riset Prilaku Konsumen, Jakarta: PT. Gramedia Pustaka. 
Fandy Tjiptono (2017), Serivce Quality and Satisfiation. Jakarta: Edisi tiga. Andi.

Freddy Rangkuti (2016) Strategi Promosi Yang Kreatif, Edisi Pertama, Cetakan Pertama Jakarta: Gramedia Pustaka Utama.

Imam Ghozali (2017). Aplikasi Analisis Multivariate Dengan Program SPSS. Edisi Kelima. Semarang: Badan Penerbit Undip.

Istijanto (2014). Riset Sumber Daya Manusia. Jakarta: PT. Gramedia Pustaka

Kharis, Ismu Fadli (2011). Studi Mengenai Impulse Buying dalam Penjualan Online. Semarang : Skripsi Universitas Diponegoro

Kotler dan Amstrong (2017), Prinsip-prinsip Pemasaran. Edisi Kedua Belas”. Jilid Satu. Jakarta: Erlangga.

Lupiyoadi (2016) Manajemen Pemasaran Jasa, Edisi 4, Jakarta: Salemba Empat.

Philip Kotler (2017) Manajemen Pemasaran, Edisi Keempat Belas, Jakarta: PT. Indeks.

Phipil Kotler dan Kevin Keller (2017) Manajemen Pemasaran, Edisi Kedua Belas, Jilid Satu, Jakarta: Erlangga.

Rao, Purba, (2012). Measuring Consumer Perceptions Through Factor Analysis. The Asian.

Santoso, Singgih (2015). Menguasai Statistik Multivariat. Jakarta: PT Elex Media Komputindo.

Sudjana (2014). Metode Statistika, Bandung: Tarsido.

Sugiyono (2017). Metode Penelitian Administrasi : dilengkapi dengan Metode R \& D. Bandung: Alfabeta. 